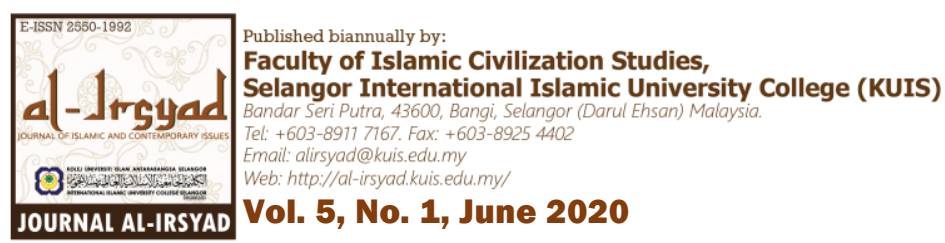

\title{
Analisis Tinjauan Literatur Sistematik (SLR) Berkaitan Penterjemahan Elemen Iltifät
}

\section{[A Systematic Literature Review (SLR) Analysis on the Translation of Iltifät Elements]}

\author{
Muhammad Hakim Kamal ${ }^{1}$, Mohamad Hussin ${ }^{2 *}$ \\ ${ }^{1}$ Jabatan Bahasa Arab dan Bahasa-bahasa Timur Tengah, Fakulti Bahasa dan Linguistik, Universiti Malaya, \\ 50603, Kuala Lumpur, Malaysia, kimkml1994@ gmail.com. \\ 2 Jabatan Bahasa Arab dan Bahasa-bahasa Timur Tengah, Fakulti Bahasa dan Linguistik, Universiti Malaya, \\ 50603, Kuala Lumpur, Malaysia, mohamadhussin@um.edu.my.
}

* Penulis penghubung: Mohamad bin Hussin. Jabatan Bahasa Arab dan Bahasa-bahasa Timur Tengah, Fakulti Bahasa dan Linguistik, Universiti Malaya, 50603, Kuala Lumpur, Malaysia. mohamadhussin@um.edu.my, Tel: (+60) 19-8081897.

\begin{tabular}{ll}
\hline Keywords: & \multicolumn{1}{c}{ ABSTRACT } \\
\cline { 2 - 3 } $\begin{array}{l}\text { Literature, Translation, } \\
\text { Iltifät, Translation Strategy, }\end{array}$ Translation studies have increasingly become popular among \\
researchers. However, the strategies of translating iltifät elements \\
which are known to affect the understanding of a given text have \\
not received much attention. This is due to the perceived complexity \\
and difficulty of translating iltifät by many scholars. However, its \\
translation strategies do require improvement so as to avoid \\
confusion among target text readers. This study presents a \\
systematic literature analysis on the translation of iltifät elements \\
with the aims of integrating previous findings and identifying new \\
research areas. This qualitative study applies a document analysis \\
approach and a systematic literature review (SLR). This analysis \\
focuses on the reviewed studies' backgrounds, issues, methods and \\
findings. The results show that previous studies in general tend to \\
focus on the corpus of the sacral text which is the Quran, \\
particularly on iltifät damīr (reference switching) and its English \\
translation strategies. The findings also show that the problems \\
arising from previous studies can be resolved by applying efficient \\
translation strategies. Therefore, future research in Arabic-Malay \\
translation that aims to produce equivalent translation strategies in \\
regards to iltifät damir elements should be emphasized.
\end{tabular}

\begin{tabular}{ll}
\hline Kata Kunci: & \multicolumn{1}{c}{ ABSTRAK } \\
\cline { 2 - 3 } Literatur; Penterjemahan; & Kajian mengenai penterjemahan semakin berkembang dan \\
Iltifät; Strategi & mendapat tumpuan dalam kalangan para pengkaji. Namun begitu, \\
Penterjemahan; Padanan & strategi penterjemahan elemen iltifät yang memberi kesan kepada \\
Makna. & makna sesuatu teks kurang diberi perhatian. Hal ini kerana \\
& kebanyakan sarjana berpendapat bahawa elemen iltifāt adalah rumit \\
& dan sukar untuk diterjemahkan. Walau bagaimanapun, strategi \\
& penterjemahannya perlu dimantapkan agar makna elemen iltifăt \\
& tidak menimbulkan kekeliruan dalam kalangan pembaca teks \\
& sasaran. Kajian ini memfokuskan kepada literatur berkaitan \\
& penterjemahan elemen iltifät dalam kajian terdahulu dan \\
\hline
\end{tabular}




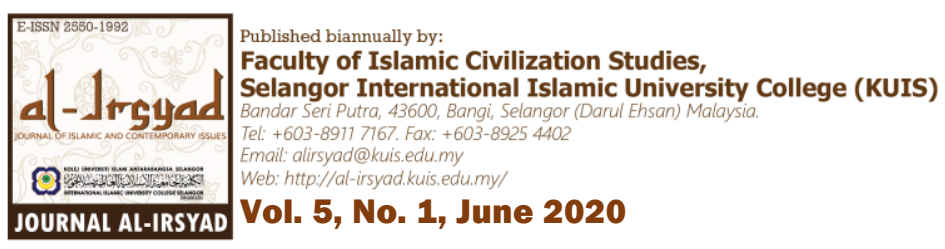

mengintegrasikan penemuan kajian lepas bagi meneroka cadangan isu baharu untuk dikaji. Kajian kualitatif ini menerapkan reka bentuk analisis dokumen dan berpandukan tinjauan literatur sistematik (systematic literature review, SLR) sebagai landasan. Analisis ini memfokuskan kepada latar belakang kajian, permasalahan, metode dan dapatan kajian terdahulu. Hasil kajian menunjukkan bahawa kajian-kajian lepas lebih menumpukan korpus teks kudus iaitu al-Quran yang berkisar tentang elemen iltifät damīr dan strategi penterjemahannya ke dalam bahasa Inggeris. Dapatan juga menunjukkan bahawa permasalahan yang timbul daripada kajian-kajian lepas dapat diatasi dengan menerapkan strategi penterjemahan tertentu. Oleh yang demikian, kajian penterjemahan Arab-Melayu yang memfokuskan kepada usaha menghasilkan strategi penterjemahan yang sepadan dalam menterjemah elemen iltifät d̦amīr wajar diketengahkan.

\section{Pengenalan}

Pelbagai kajian penterjemahan telah dilakukan oleh sarjana, seperti Nida (1964), Catford (1965), Newmark (1988), Venuti (2000), dan Bell (2012). Bell (2012) mengatakan bahawa definisi terjemahan terbahagi kepada tiga. Pertama, terjemahan ialah proses atau perlakuan menterjemah, aktiviti yang bukan dalam bentuk fizikal. Kedua, terjemahan ialah suatu karya, produk daripada proses penterjemahan. Ketiga, terjemahan datang dengan maksud konsep menterjemah dan produk yang terhasil daripada proses penterjemahan. Namun begitu, hakikatnya semua definisi terjemahan mempunyai ciri yang sama iaitu proses perluasan maklumat yang melangkaui sempadan bahasa, budaya, geografi serta perkaitannya dengan masa (Abu Bakar, 2012). Menurut Wuryantoro (2018) penterjemah mestilah menguasai bahasa sumber dan bahasa sasaran, bidang ilmu dalam teks sumber dan strategi penterjemahan kerana penterjemahan merupakan proses pengalihan makna dari bahasa sumber ke bahasa sasaran.

Dalam bahasa Arab, gaya bahasa yang paling kerap digunakan khususnya dalam al-Quran ialah elemen iltifāt (Asnawi, 2017; al-Dalīmiy \& Nūrī, 2009; Zaenuddin, 2018). Iltifāt secara amnya melibatkan pertukaran elemen bahasa dalam sesuatu ayat dan fungsi umumnya adalah untuk menjadikan ujaran lebih memberi kesan dan tidak membosankan pendengar (Amirudin, 2013). Dapatan kajian Tabl (1998) menunjukkan bahawa elemen iltifät digunakan lebih daripada 800 kali dalam al-Quran. Maka, tidak hairanlah didapati iltifät merupakan gaya bahasa yang paling banyak digunakan dalam surah al-Kahfi iaitu sebanyak 53 kali pengulangan penggunaannya (Lakhḍar, 2016). Begitu juga dalam surah al-Nisā' iaitu dengan 32 kali kekerapan penggunaannya (Harti, 2018).

Dari sudut kajian penterjemahan, Ibraheem \& al-Bagoa' (2010), al-Badani, et. al. (2014) dan Amirdabbaghian (2017) menegaskan bahawa elemen iltifät kurang diberi perhatian oleh para pengkaji dan penterjemah. Sedangkan penerapan elemen iltifät dalam sesuatu teks mewujudkan kohesi dan memberikan kesan kepada kefahaman tentang teks terjemahan (Būsyāqūr, 2007; Mahinnaz, et. al., 2012). Pengabaian elemen iltifät dalam penterjemahan menyebabkan berlaku penyelewengan makna sebenar yang terkandung dalam teks sumber (Ibraheem \& al-Bagoa', 2010).

Justeru, kajian ini bertujuan untuk mengenal pasti tema kajian lepas berkaitan penterjemahan iltifät, menilai secara kritis fokus kajian lepas dan mengintegrasi penemuan kajian lepas sebagai cadangan isu baru untuk dikaji.

\section{Permasalahan Kajian}

Penterjemahan merupakan tugas yang sukar terutamanya jika melibatkan elemen bahasa yang dianggap janggal atau tiada persamaan dengannya dalam bahasa sasaran. Contohnya elemen iltifät yang terdapat dalam bahasa Arab tetapi tiada dalam sistem bahasa lain. Meskipun gaya bahasa iltifät wujud dan sebati dalam kalangan orang Arab, namun elemen ini dianggap asing dan ganjil dalam kalangan orang Barat (Abdul Raof, 2005; Omer, 2017; Robinson, 1996). Noldeke dalam Akbari (2018) mengatakan bahawa iltifät yang terkandung dalam al-Quran 


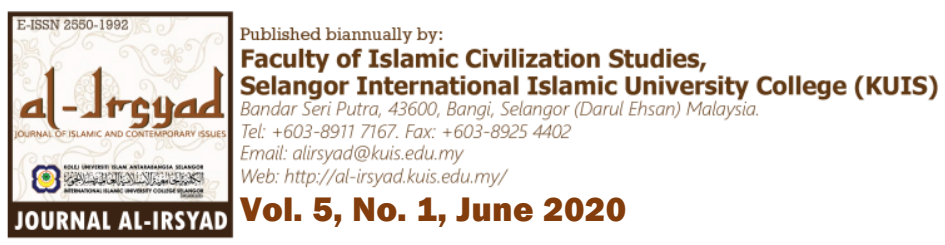

kelihatan janggal dan tidak indah. Malahan menurut Burton (1988), Rafiqul-Haqq \& Newton (1996) serta Robinson (1996), elemen iltifät adalah kesalahan tatabahasa Arab yang terdapat dalam al-Quran al-Karim.

Ali (2015) pula menegaskan bahawa kajian yang berkaitan dengan penterjemahan elemen iltifät didapati kurang terperinci dan komprehensif. Hakikatnya, elemen iltifät mewujudkan kohesi dan memberikan kesan kepada kefahaman tentang sesuatu teks sasaran (Būsyāqūr, 2007; Mahinnaz, et. al., 2012). Namun begitu, al-Quran \& al-Azzam (2009), Ibraheem \& Al-Bagoa' (2010), Hassan (2011), al-Farisi (2015), al-Badani, et. al. (2016), Amirdabbaghian (2017) serta Horri (2019) menegaskan bahawa penterjemahan elemen iltifät ke bahasa sasaran adalah sukar. Hal ini demikian kerana perbezaan antara tatabahasa Arab dengan tatabahasa bahasa sasaran (al-Thawābiyyat, 2019). Maka, tiada hairanlah apabila Hatim \& Mason (1997) berpendapat bahawa tiada gaya bahasa yang menyerupai elemen iltifāt dalam bahasa Inggeris. Begitu juga Būsyāqūr (2007) yang mengatakan bahawa tiada persamaan antara elemen iltifāt dengan mana-mana gaya bahasa yang terdapat dalam bahasa Perancis.

Selain itu, Zaenuddin (2018), al-Farisi (2015) dan al-Farisi (2017) menegaskan bahawa berkemungkinan besar terdapat kesilapan dalam teks terjemahan elemen iltifāt. Contohnya, penterjemahan iltifāt damīr [pertukaran kata ganti nama] yang mana kewujudan dua kata ganti nama yang berbeza namun keduaduanya merujuk kepada entiti yang sama (al-Farisi, 2017). Menurut Abdullah (2017) situasi ini menyumbang kepada kejanggalan ayat terjemahan seterusnya, menjadi punca ketidakbolehbacaan teks terjemahan al-Quran. Antaranya, firman Allah SWT dalam surah 'Abasa [80] ayat 1-3:

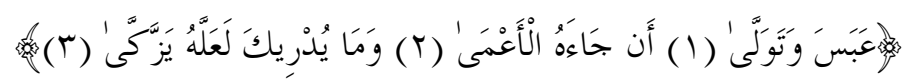

Terjemahan:

"Ia memasamkan muka dan berpaling (1) Kerana ia didatangi orang buta (2) dan apa jalannya engkau dapat mengetahui (wahai Muhammad akan tujuannya) barangkali ia mahu membersihkan hatinya (dengan pelajaran agama yang didapatinya daripadamu (3).”

Ayat ini diturunkan sebagai teguran kepada nabi Muhammad SAW supaya memberi layanan yang selayaknya kepada orang yang ingin memeluk Islam meskipun seseorang itu miskin dan tidak berpengaruh (Basmeih, 1983: 1352). Ayat berkenaan mengandungi elemen iltifāt iaitu kata ganti nama هُ [ia] dalam kata kerja عَبَ [ia memasamkan muka] ditukar kepada kata ganti nama أَنْتَ [engkau] yang ditambat dengan kata kerja يُدري [engkau dapat mengetahui] dan kedua-dua kata ganti nama ini merujuk kepada Rasulullah SAW (alFarisi, 2015). Walau bagaimanapun, terjemahan ayat iltifät berkenaan ke teks sasaran adalah kabur. Hal ini

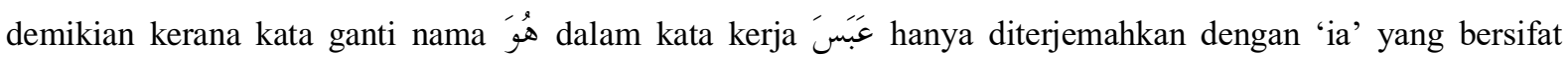
umum walhal individu berkenaan secara khususnya merujuk kepada nabi Muhammad SAW (al-Farisi, 2015). Keadaan ini menyebabkan kekeliruan dalam memahami makna sebenar ayat. Ini kerana makna yang terkandung dalam teks sasaran berkemungkinan berbeza dengan makna sebenar dalam teks sumber kesan dari penggunaan elemen iltifāt (Amirdabbaghian, 2017). Banyak contoh lain yang ditemui dalam terjemahan al-Quran. Antaranya firman Allah SWT dalam surah Yünus [10] ayat 22:

Terjemahan:

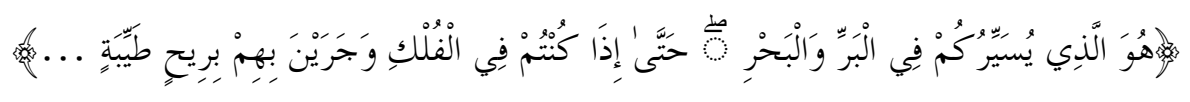

"Dialah yang menjalankan $\underline{\mathbf{k a m u}}$ di darat dan di laut (dengan diberi kemudahan menggunakan berbagai jenis kenderaan); sehingga apabila kamu berada di dalam bahtera dan bahtera itu pula bergerak laju membawa penumpang-penumpangnya dengan tiupan angin yang baik..."

Dalam ayat ini, terdapat elemen iltifāt iaitu kata ganti nama أََُْْ [kamu] ditukar kepada kata ganti nama is [penumpang-penumpang] dan kedua-dua kata ganti nama ini merujuk kepada golongan yang sama iaitu orang kafir (Basmeih, 1983). Didapati bahawa terjemahan bagi kata ganti nama \$s yang ditambat dengan 


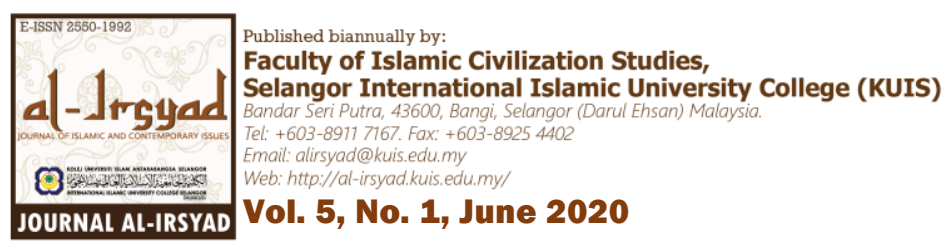

partikel jarr ب diubah daripada 'mereka' kepada 'penumpang-penumpang'. Hal ini kerana sekiranya terjemahan dikekalkan dengan 'mereka' iaitu dengan andaian "sehingga apabila kamu berada di dalam bahtera dan bahtera itu pula bergerak laju membawa mereka...”, maka terjemahan ini seakan-akan mengisyaratkan bahawa bahtera hanya membawa 'mereka' dan tidak membawa 'kamu'.

Seterusnya, dapatan al-Banāniy (1993), Qaḥțān (2005), Būsyāqūr (2007) dan al-Dīn (2018) masingmasing menunjukkan bahawa elemen iltifāt mempunyai pelbagai fungsi balaghah. Iltifāt dari jenis yang sama pula berkemungkinan mengandungi lebih daripada satu fungsi. Contohnya, firman Allah SWT dalam surah alInsān [76] ayat 21-22:

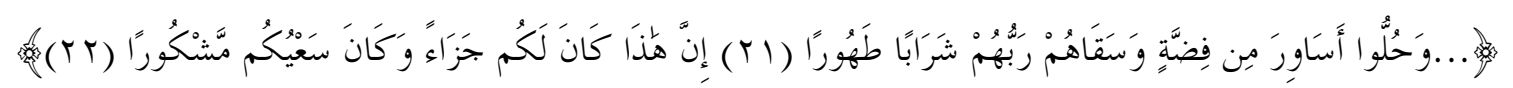

Terjemahan:

“...Dan mereka dihiasi dengan gelang-gelang tangan dari perak; dan mereka diberi minum oleh Tuhan mereka dengan jenis minuman (yang lain) - yang bersih suci (21) (serta dikatakan kepada mereka): "sesungguhnya (segala pemberian) ini adalah untuk $\underline{\mathbf{k a m u}}$ sebagai balasan, dan adalah usaha amal $\underline{\text { kamu }}$ (di dunia dahulu) diterima dan dihargai (oleh Allah).”

Dalam ayat ini, terdapat elemen iltifāt iaitu kata ganti nama هُ [mereka] ditukar kepada kata ganti nama أَنْهُ [ [kamu semua] dan kedua-dua kata ganti nama ini merujuk kepada orang beriman (al-Jarmān, 2016). Ibn 'Āsyūr (1984) mengatakan bahawa iltifāt berkenaan mengisyaratkan kepada pujian terhadap lawan tutur iaitu orang beriman. Namun begitu, Abū al-Su'ūd (t.th.) menegaskan bahawa iltifāt dari kata ganti nama ketiga kepada kata ganti nama kedua dalam sesuatu ayat juga bertujuan mencela lawan tutur. Misalnya, Allah SWT berfirman dalam surah al-An' 'àm [6] ayat 1-2:

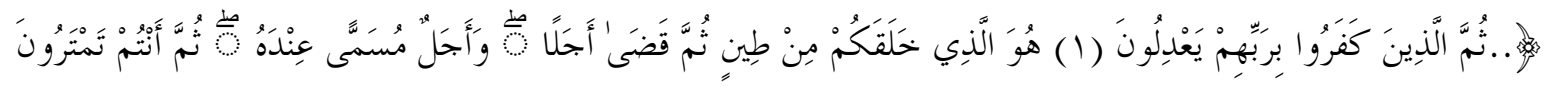

Terjemahan:

“...dalam pada itu, orang-orang kafir menyamakan (sesuatu yang lain) dengan Tuhan mereka (1) Dialah yang menjadikan kamu dari tanah, kemudian ia tentukan ajal (kematian kamu) dan satu ajal lagi yang tertentu di sisiNya (iaitu masa yang telah ditetapkan untuk dibangkitkan kamu semula pada hari kiamat); dalam pada itu, kamu masih ragu-ragu (tentang hari pembalasan)."

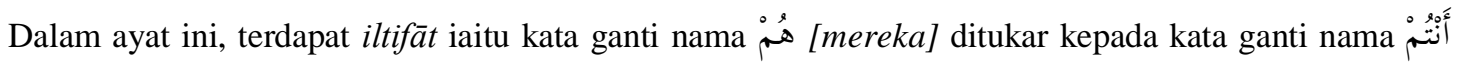
[kamu] dan kedua-dua ganti nama ini merujuk kepada orang kafir (al-Banāniy, 1993). Menurut Abū al-Su'ūd (t.th.) elemen iltifät dalam ayat berkenaan bertujuan mencela lawan tutur iaitu orang kafir. Namun, suatu yang jelas ialah balaghah iltifāt ini tidak menyerlah dalam teks terjemahan Arab-Melayu di atas. Kesannya, makna sebenar ayat iltifāt tidak dikesan sekaligus maknanya akan berbeza dengan makna yang ditonjolkan dalam teks terjemahan.

Oleh yang demikian, melihat kepada realiti ini, kajian yang memfokuskan kepada tinjauan literatur berkaitan dengan penterjemahan elemen iltifät dilakukan dan permasalahan yang boleh diketengahkan sebagai kajian baharu pada masa kini diteliti.

\section{Metodologi Kajian}

Kajian ini merupakan kajian kualitatif yang menggunakan kaedah tinjauan literatur sistematik [systematic literature review (SLR)] bertujuan untuk mengenal pasti, menilai secara kritis dan mengintegrasikan penemuan semula kajian (Bem, 1995; Baumeister \& Leary, 1997). Justifikasi metode ini digunakan adalah kerana kesesuaian dan kerelevanannya dalam menilai secara sistematik keseluruhan kajian yang berkaitan dengan 


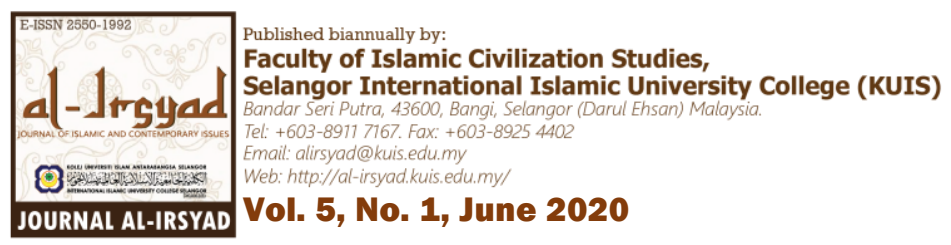

penterjemahan elemen iltifät dari tahun ke tahun sekali gus menjelaskan isu baharu dari satu sudut. Kaedah ini menerapkan carian sistematik untuk mengenal pasti penterjemahan elemen iltifăt. Metode kajian yang digunakan ialah analisis dokumen terhadap artikel, jurnal, tesis dan buku yang ditulis oleh para sarjana. Kadar rujukan adalah bermula dari tahun 2007 hingga tahun 2019. Kajian lepas diambil bermula dari tahun 2007 kerana merujuk kepada dapatan dalam jadual 1 dan jadual 2, perbincangan berkaitan dengan penterjemahan elemen iltifāt mula dibahas dan dikaji pada tahun tersebut.

Kajian ini menerapkan kaedah tinjauan literatur sistematik (SLR) yang merangkumi tahun kajian, latar belakang, permasalahan kajian, metode dan dapatan kajian. Kaedah ini mengaplikasikan carian yang sistematik untuk mengenal pasti keperluan strategi penterjemahan yang mampan dalam menghasilkan terjemahan elemen iltifät yang sepadan. Hakikatnya, prinsip tinjauan literatur sistematik (SLR) diterapkan oleh ramai pengkaji mutakhir ini bagi menyorot sejauh mana fenomena yang berlaku di sekitar kata kunci kajian (Michie \& Williams, 2003; Siddiqi, et. al., 2006). Dalam kajian ini, kata kunci 'penterjemahan iltifät', 'the translation of reference switching' digunakan bagi mendapatkan data kajian. Kajian ini dibantu dengan akses pangkalan data google, researchgate dan academia. Hasil carian dokumen yang berkaitan dengan kajian, hanya 16 sahaja diterima untuk dianalisis dalam SLR dan skop carian bermula dari tahun 2007 hingga tahun 2019.

Dalam kajian balaghah Arab, iltifāt diletakkan sebagai salah satu perbahasan ilmu bad̄̄'. Secara

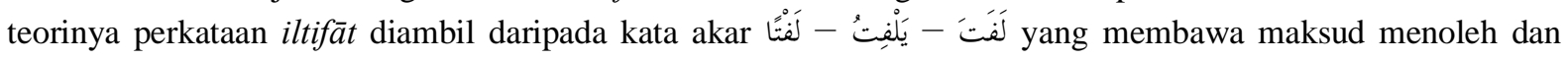
memalingkan sesuatu (al-Asfahāniy, 2009: 743; al-Fayrūzābādiy, 2005: 159; Ibn Manẓūr, 1993/2: 84-85). Ibn Fāris (1979/5: 258) pula menegaskan bahawa iltifăt memberi makna sesuatu yang menyimpang dari laluan biasa. Menurut al-Zamakhsyariy (1998: 173), iltifät bermaksud mengupas sesuatu seperti kulit kayu. Berdasarkan maklumat perkamusan ini, jelas menunjukkan bahawa makna iltifät dari sudut bahasa membawa erti menoleh, memalingkan sesuatu, menyimpang dari laluan biasa atau mengupas sesuatu.

Manakala dari sudut istilah terdapat dua pendekatan para sarjana dalam membahaskan konsep iltifät. Pertama, pendekatan kebanyakan sarjana seperti al-Așma'iy, Abū 'Ubaydaț, al-Mubarrad, Ibn al-Mu'tazz, al'Askariy dan al-Maydāniy yang menegaskan bahawa iltifāt melibatkan pertukaran d̦āmīr [kata ganti nama] iaitu d̦amìr ghā'ib [kata ganti nama ketiga], d̦amīr mukhāțab [kata ganti nama kedua] dan ḍamī mutakallim [kata ganti nama pertama] iaitu pertukaran salah satu daripada kata ganti nama berkenaan kepada kata ganti nama yang lain (Fatimah, 2015; Ismā'îl, 2011; Mukhtar, 2018; Rābhịy, 2014). Kedua, pendekatan sebahagian sarjana iaitu al-Sakkākiy, Ibn al-Athīr dan al-'Alawiy yang meluaskan konsep iltifāt. Mereka berpandangan bahawa iltifät adalah pertukaran elemen bahasa ke elemen bahasa yang lain seperti pertukaran damìr [pola kata ganti nama], șìghat [pola perkataan], 'adad [pola bilangan], adawāt [pola partikel], binā' naḥwiy [pola ayat] dan pertukaran mu ‘jam [pola kosa kata] (Khadījat, 2015). Kesimpulannya, iltifāt melibatkan pertukaran elemen bahasa dalam ayat dan fungsi umumnya adalah untuk menjadikan ujaran lebih memberi kesan dan menarik pendengar.

\section{Dapatan Dan Perbincangan}

\subsection{Tema Kajian Lepas Berkaitan Penterjemahan Iltifät}

Objektif pertama adalah untuk mengenal pasti tema kajian lepas berkaitan penterjemahan iltifät. 16 tinjauan literatur telah dikenal pasti memfokuskan kepada penterjemahan elemen iltifät. Jika diperhalusi, terdapat dua tema yang melatari kajian berkenaan. Pertama, kesan penggunaan elemen iltifăt terhadap teks sasaran. Kedua, strategi penterjemahan iltifät. Kajian mengenai kesan penggunaan elemen iltifăt terhadap teks sasaran berjumlah 6 kajian iaitu:

Jadual 1. Kesan penggunaan elemen iltifät terhadap teks sasaran

\begin{tabular}{|c|c|c|c|c|c|}
\hline Bil & Kajian & Latar belakang & Permasalahan kajian & Metode & Dapatan \\
\hline 1. & $\begin{array}{l}\text { Dawood } \\
(2008)\end{array}$ & $\begin{array}{l}\text { Fungsi balaghah iltifät fi'l } \\
\text { [pertukaran kata kerja] } \\
\text { dalam terjemahan al-Quran } \\
\text { versi bahasa Inggeris. }\end{array}$ & $\begin{array}{l}\text { Meneliti kesan iltifāt fi l } \\
\text { dalam al-Quran terhadap teks } \\
\text { bahasa Inggeris nukilan Ali. }\end{array}$ & $\begin{array}{l}\text { Kualitatif, } \\
\text { analisis } \\
\text { deskriptif }\end{array}$ & $\begin{array}{l}\text { Elemen iltifät fil dalam al-Quran } \\
\text { yang datang dengan fungsi balaghah } \\
\text { tertentu diterjemahkan dengan strategi } \\
\text { penterjemahan literal. }\end{array}$ \\
\hline
\end{tabular}




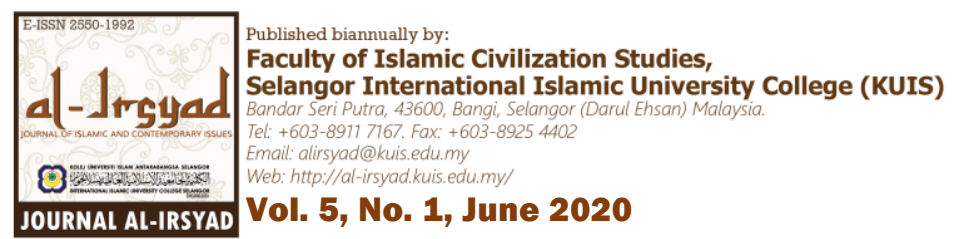

\begin{tabular}{|c|c|c|c|}
\hline Bil & Kajian & Latar belakang & Permasalahan kajian \\
\hline 2. & $\begin{array}{l}\text { al-Quran } \\
\& \\
\text { al-Azzam } \\
\text { (2009) }\end{array}$ & $\begin{array}{l}\text { Kesukaran penterjemahan } \\
\text { iltifät damìr dalam al- } \\
\text { Quran ke bahasa Inggeris. }\end{array}$ & $\begin{array}{l}\text { Kajian ini dilaksanakan bagi } \\
\text { membuktikan kehilangan } \\
\text { iltifät damìr dalam teks } \\
\text { terjemahan al-Quran versi } \\
\text { bahasa Inggeris nukilan } \\
\text { Pickthall, Ali dan Arberry. } \\
\text { Juga bertujuan membuktikan } \\
\text { bahawa teks sasaran gagal } \\
\text { memaparkan fungsi balaghah } \\
\text { iltifät damìr. }\end{array}$ \\
\hline 3. & $\begin{array}{l}\text { Ibraheem } \\
\& \\
\text { al-Bagoa' } \\
(2010)\end{array}$ & $\begin{array}{l}\text { Penterjemahan iltifāt d̦amīr } \\
\text { dalam al-Quran ke bahasa } \\
\text { Inggeris. }\end{array}$ & $\begin{array}{l}\text { Menganalisis terjemahan } \\
\text { iltifāt damīr dalam al-Quran } \\
\text { versi bahasa Inggeris nukilan } \\
\text { Dawood, Hilāliy \& Khān } \\
\text { serta Arberry. }\end{array}$ \\
\hline
\end{tabular}

\begin{tabular}{ll}
\multicolumn{1}{c}{ Metode } & \multicolumn{3}{c}{ Dapatan } \\
Kualitatif, & Elemen iltifät damīr adalah gaya \\
analisis & bahasa yang rumit dan \\
deskriptif & penterjemahannya bertembung \\
& dengan kesan linguistik yang mana \\
& masalah ini boleh diatasi dengan \\
& menerapkan pelbagai usaha untuk \\
& menyerlahkan elemen iltifät damìr \\
& dan fungsi balaghahnya dalam teks \\
& sasaran.
\end{tabular}

Kualitatif, Elemen iltifāt damīr hilang analisis sepenuhnya dalam teks sasaran. Selain deskriptif itu, penentuan entiti yang dimaksudkan oleh iltifāt damīr juga adalah isu terutama elemen iltifāt damīr dalam ayat yang sama.

4. Mahinna Pengaruh elemen iltifāt $\mathrm{z}$ et al. damīr kepada kohesi teks (2012) terjemahan al-Quran versi bahasa Inggeris

Meneliti kesan penggunaan iltifāt damīr dalam al-Quran terhadap kohesi teks sasaran bahasa Inggeris

Kualitatif, Terdapat kecacatan dari sudut kohesi analisis teks terjemahan al-Quran versi bahasa deskriptif Inggeris kesan daripada penterjemahan iltifät damīr.

Menganalisis strategi penterjemahan Ali terhadap elemen iltifāt damīr dalam surah al-Baqarat ke bahasa Inggeris.
6. Amirdab Kesan penterjemahan iltifāt baghian dāmir terhadap elemen (2017) pelibat wacana [tenor of discourse] dalam teks terjemahan al-Quran versi bahasa Inggeris.
Kajian memfokuskan kepada penterjemahan Abdel Haleem terhadap iltifāt dāmir dalam al-Quran dan kesannya terhadap pelibat wacana [tenor of discourse] dalam teks sasaran bahasa Inggeris.
Kualitatif, analisis deskriptif
Kualitatif, analisis deskriptif

Ali tidak memberikan perhatian kepada penterjemahan iltifät damìr. Hakikatnya, setiap iltifāt ḍamīr datang dengan fungsi balaghah tertentu. Kekeliruan dalam memahami makna iltifāt d̦amīr dalam teks terjemahan alQuran menyebabkan pembaca menganggap al-Quran kurang kohesi dan gramatis.

Abdel Haleem gagal menterjemahkan makna sebenar iltifāt damīr ke bahasa Inggeris. Hal ini kerana elemen pelibat wacana dalam teks sasaran yang mengandungi iltifāt d̦amīr berbeza dengan elemen pelibat wacana dalam teks sumber. Ini menyebabkan pembaca teks sasaran tidak memperoleh makna sebenar yang terkandung dalam elemen iltifāt damīr.

Manakala 11 literatur didapati berkisar tentang strategi penterjemahan iltifät. Kajian-kajian berkenaan ialah:

Jadual 2. Strategi penterjemahan iltifāt

\begin{tabular}{|c|c|c|c|c|c|}
\hline Bil & Kajian & Latar belakang & Permasalahan kajian & Metode & Dapatan \\
\hline 1. & $\begin{array}{l}\text { Būsyāqūr } \\
\text { (2007) }\end{array}$ & $\begin{array}{l}\text { Elemen iltifät dalam } \\
\text { al-Quran } \\
\text { penterjemahannya ke } \\
\text { bahasa Perancis. }\end{array}$ & $\begin{array}{l}\text { Mengenal pasti fungsi balaghah } \\
\text { iltifāt șighat [pertukaran pola } \\
\text { perkataan], iltifāt 'adad } \\
\text { [pertukaran pola bilangan], } \\
\text { iltifāt damīr [pertukaran kata } \\
\text { ganti nama], iltifāt adawāt } \\
\text { [pertukaran pola partikel], }\end{array}$ & $\begin{array}{l}\text { Kualitatif, } \\
\text { analisis } \\
\text { deskriptif. }\end{array}$ & $\begin{array}{l}\text { Fungsi balaghah iltifät ditentukan oleh } \\
\text { konteks yang melatari ayat. Selain itu, } \\
\text { elemen iltifät memberikan kesan } \\
\text { kepada kefahaman tentang teks } \\
\text { terjemahan dan strategi pentafsiran } \\
\text { adalah strategi terbaik dalam } \\
\text { menterjemahkan elemen iltifät. }\end{array}$ \\
\hline
\end{tabular}

iltifāt binā' nahwiy [pertukaran pola ayat] dan iltifāt mu jam [pertukaran kosa kata] dalam al-Quran dan kesannya terhadap teks terjemahan. Di samping itu, kajian bertujuan mengenal pasti strategi penterjemahan Hamzat, Hamīdullāh dan Mason terhadap elemen iltifāt dalam al-Quran ke bahasa Perancis. 


\begin{tabular}{|c|c|c|c|c|c|}
\hline Bil & Kajian & Latar belakang & Permasalahan kajian & Metode & Dapatan \\
\hline 2. & $\begin{array}{l}\text { Elgebaly } \\
\text { (2012) }\end{array}$ & $\begin{array}{lr}\text { Keperluan penonton } \\
\text { rancangan TV dalam } \\
\text { teks sarikata yang } \\
\text { mengandungi } & \text { iltifāt } \\
\text { damīr. } & \end{array}$ & $\begin{array}{l}\text { Memberi gambaran bagaimana } \\
\text { penyari kata rancangan TV } \\
\text { siaran Iqraa satellite } \\
\text { melakukan modifikasi terhadap } \\
\text { elemen iltifät damīr }\end{array}$ & $\begin{array}{l}\text { Kualitatif, } \\
\text { analisis } \\
\text { deskriptif }\end{array}$ & $\begin{array}{l}\text { Penyari kata melakukan modifikasi } \\
\text { terhadap elemen iltifät damīr supaya } \\
\text { mesej yang ingin disampaikan mudah } \\
\text { difahami dan jelas kepada penonton } \\
\text { yang tidak biasa dengan budaya Arab. } \\
\text { Strategi penterjemahan yang } \\
\text { diterapkan oleh penyari kata ialah } \\
\text { penterjemahan } \\
\text { [paraphrase], parafrasa } \\
\text { [condensation] dan pengembangan } \\
\text { makna [expansion] }\end{array}$ \\
\hline 3. & $\begin{array}{l}\text { al-Badani } \\
\text { et al. } \\
(2014)\end{array}$ & $\begin{array}{l}\text { Analisis tekstual } \\
\text { terhadap } \\
\text { penterjemahan iltifāt } \\
\text { damīr dalam surah al- } \\
\text { Baqarat ke bahasa } \\
\text { Inggeris. }\end{array}$ & 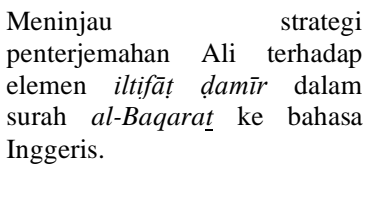 & $\begin{array}{l}\text { Kualitatif, } \\
\text { analisis } \\
\text { tesktual }\end{array}$ & $\begin{array}{l}\text { Tiada penampakan elemen iltifāt } \\
\text { damīr dalam terjemahan Ali. Strategi } \\
\text { penterjemahan literal didapati tidak } \\
\text { sesuai digunakan dalam menterjemah } \\
\text { iltifät damìr yang datang dengan } \\
\text { fungsi balaghah tertentu. }\end{array}$ \\
\hline 4. & $\begin{array}{l}\text { al-Farisi } \\
(2015)\end{array}$ & $\begin{array}{l}\text { Masalah } \\
\text { penterjemahan iltifāt } \\
\text { damīr dalam al-Quran } \\
\text { ke bahasa Indonesia. }\end{array}$ & $\begin{array}{l}\text { Kajian ini dilaksanakan bagi } \\
\text { meneliti strategi penterjemahan } \\
\text { dan ideologi Kementerian Hal } \\
\text { Ehwal Agamar Indonesia } \\
\text { (KHEAI) } \\
\text { menterjemahkan iltifät damīr } \\
\text { ke bahasa Indonesia. }\end{array}$ & $\begin{array}{l}\text { Kualitatif, } \\
\text { analisis } \\
\text { deskriptif }\end{array}$ & $\begin{array}{l}\text { KHEAI cenderung kepada strategi } \\
\text { penterjemahan literal iaitu sebanyak } \\
60.16 \% \text { iltifät damīr dalam al-Quran } \\
\text { diterjemahkan dengan strategi } \\
\text { berkenaan. Strategi penterjemahan } \\
\text { literal ini } \\
\text { kecenderungan KHEAI kepada } \\
\text { ideologi keutamaan kepada konsep } \\
\text { bahasa sumber dalam penterjemahan } \\
\text { [foreignization]. }\end{array}$ \\
\hline
\end{tabular}

5. al-Badani Penterjemahan iltifāt et al. damīr dalam surah al(2015) Baqarat ke bahasa Inggeris.
Menganalisis

penterjemahan Ali terhadap elemen iltifāt damīr dalam surah al-Baqarat ke bahasa Inggeris.
6. Ali (2015) Pendekatan penterjemahan iltifāt șighat dalam al-Quran ke bahasa Inggeris.

7. al-Badani et 2016$)$ al. pengembangan makna [expansion strategy] dalam penterjemahan iltifāt d̦amìr dalam surah al-Baqarat ke bahasa Inggeris.

8. al-Faris (2017)
Ideologi dan strategi penterjemah dalam menterjemahkan iltifāt damīr dalam al-Quran ke bahasa Indonesia.
Kajian memfokuskan kepada strategi penterjemahan Zidan \& Zidan, Hilāliy \& Khān, Ghāliy serta Abdel Haleem terhadap elemen iltifāt șighat dalam alQuran ke bahasa Inggeris.

Kajian melihat sejauh mana keberkesanan strategi pengembangan makna yang diterapkan oleh Ali dalam menghasilkan terjemahan iltifät damīr yang sepadan.

Meneliti ideologi dan strategi Thalib dalam menterjemahkan iltifāt ḍamīr dalam al-Quran ke bahasa Indonesia.
Kualitatif, analisis deskriptif
Ali tidak memberikan perhatian kepada penterjemahan iltifāt damīr. Hakikatnya, setiap iltifāt damīr datang dengan fungsi balaghah tertentu. Kekeliruan dalam memahami makna iltifät ḍamīr dalam teks terjemahan alQuran menyebabkan pembaca menganggap al-Quran kurang kohesi dan gramatis.

Kualitatif, Teori schema sesuai diterapkan oleh analisis penterjemah ketika dalam proses deskriptif. penterjemahan iltifāt șīghat. Strategi pentafsiran sangat digalakkan ketika menterjemah iltifāt șĭghat.

Kualitatif, Strategi pengembangan makna dalam analisis penterjemahan iltifāt damir masih deskriptif gagal menyerlahkan makna sebenar yang dikehendaki oleh elemen iltifāt damīr.
Kualitatif, Thalib menerapkan strategi analisis penterjemahan transposition kandungan [perubahan kategori tatabahasa], amplification [penambahan info implisit dalam teks sasaran] dan reduction [pemadatan bahasa sumber] yang mana menyebabkan pengalihan dari sudut fungsi dan sintaksis dalam teks terjemahan.

Kualitatif, analisis deskriptif
Strategi huraian [explication] adalah teknik yang kerap digunakan oleh penterjemah al-Quran bagi mengatasi isu halangan terjemahan [translation 


\begin{tabular}{|c|c|c|c|c|}
\hline 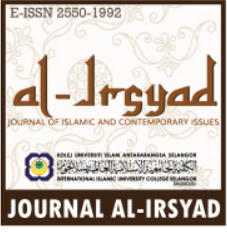 & \multicolumn{4}{|c|}{$\begin{array}{l}\text { Published biannually by: } \\
\text { Faculty of Islamic Civilization Studies, } \\
\text { Selangor International Islamic University College (KUIS) } \\
\text { Bandar Seri Putra, } 43600, \text { Bangi, Selangor (Darul Ehsan) Malaysia. } \\
\text { Tel: +603-8911 } 7167 . \text { Fax: }+603-89254402 \\
\text { Email: alirsyad@kuisedu.my } \\
\text { Web: http://al-irsyad.kuis.edu.my/ } \\
\text { Vol. 5, No. 1, June } 2020\end{array}$} \\
\hline Kajian & Latar belakang & Permasalahan kajian & Metode & Dapatan \\
\hline & $\begin{array}{l}\text { mu jam [pertukaran } \\
\text { kosa kata] dalam al- } \\
\text { Quran ke bahasa } \\
\text { Inggeris. }\end{array}$ & $\begin{array}{l}\text { Sarwar, Shakir, Sher Ali dan } \\
\text { Ali terhadap elemen iltifät } \\
\text { sīghat dan iltifät mu jam dalam } \\
\text { al-Quran ke bahasa Inggeris. }\end{array}$ & & barriers]. \\
\hline $\begin{array}{l}\text { al- } \\
\text { Thawābiyy } \\
\text { at } \\
(2019)\end{array}$ & $\begin{array}{l}\text { Masalah } \\
\text { penterjemahan iltifāt } \\
\text { 'adad [pertukaran } \\
\text { pola bilangan] dalam } \\
\text { al-Quran ke bahasa } \\
\text { Inggeris. }\end{array}$ & $\begin{array}{l}\text { Meneliti strategi penterjemahan } \\
\text { Ali, Hilāliy \& Khān, Rodwell } \\
\text { dan Irving terhadap elemen } \\
\text { iltifāt 'adad dalam al-Quran ke } \\
\text { bahasa Inggeris dan kesannya } \\
\text { terhadap padanan makna dalam } \\
\text { teks sasaran. }\end{array}$ & $\begin{array}{l}\text { Kualitatif, } \\
\text { analisis } \\
\text { deskriptif }\end{array}$ & $\begin{array}{l}\text { Ali, Khan, Redwill dan Irfin tidak } \\
\text { menerapkan strategi khusus dalam } \\
\text { menterjemahkan iltifāt adad. } \\
\text { Kesannya, terjemahan yang dihasilkan } \\
\text { oleh mereka menyebabkan kekaburan } \\
\text { dan kekeliruan makna dalam teks } \\
\text { sasaran. }\end{array}$ \\
\hline $\begin{array}{l}\text { Horri } \\
(2019)\end{array}$ & $\begin{array}{l}\text { Dominasi terjemahan } \\
\text { semantik dalam } \\
\text { penterjemahan iltifāt } \\
\text { damīr dalam al-Quran } \\
\text { ke bahasa Inggeris. }\end{array}$ & $\begin{array}{l}\text { Kajian bertujuan menganalisis } \\
\text { strategi penterjemahan Ali, } \\
\text { Pickthall dan Arberry terhadap } \\
\text { elemen iltifät damìr dalam al- } \\
\text { Quran ke bahasa Inggeris. }\end{array}$ & $\begin{array}{l}\text { Kualitatif, } \\
\text { analisis } \\
\text { deskriptif }\end{array}$ & $\begin{array}{l}\text { Terjemahan semantik adalah strategi } \\
\text { penterjemahan yang paling kerap } \\
\text { digunakan dalam menterjemah iltifät } \\
\text { damīr. Ini juga menunjukkan bahawa } \\
\text { ideologi Ali, Pickthall dan Arberry } \\
\text { adalah keutamaan konsep bahasa } \\
\text { sumber dalam penterjemahan } \\
\text { [foreignization]. }\end{array}$ \\
\hline
\end{tabular}

\subsection{Fokus Kajian Lepas Berkaitan Penterjemahan Iltifät}

Objektif kedua kajian adalah untuk menilai secara kritis fokus kajian lepas berkaitan penterjemahan iltifăt. Berdasarkan jadual 1 dan jadual 2, dapat dibuat beberapa kesimpulan terhadap tinjauan literatur sistematik (SLR) dari sudut fokus kajian lepas berkaitan penterjemahan iltifät seperti berikut:

\subsubsection{Isu kajian}

Merujuk kepada jadual 1 dan jadual 2, terdapat 16 kajian yang berkaitan dengan penterjemahan elemen iltifät. Isu kajian yang dfokuskan oleh para pengkaji terdahulu lebih tertumpu kepada strategi penterjemah yang mana terdapat 11 kajian membincangkan strategi penterjemahan elemen iltifăt ke bahasa sasaran. Hanya 5 sahaja kajian yang menyentuh kesan penggunaan elemen iltifät terhadap teks sasaran iaitu Fungsi Balaghah Iltifät Fi 'l [Pertukaran Kata Kerja] dalam Terjemahan al-Quran versi Bahasa Inggeris, Kesukaran Penterjemahan Iltifät Damīr dalam al-Quran ke Bahasa Inggeris, Penterjemahan Iltifät Damīr dalam al-Quran ke Bahasa Inggeris, Pengaruh Elemen Iltifät Damīr kepada Kohesi Teks Terjemahan al-Quran versi Bahasa Inggeris, Kesan Penterjemahan Iltifät Dāmir Terhadap Elemen Pelibat Wacana [Tenor of Discourse] dalam Teks Terjemahan al-Quran versi Bahasa Inggeris. Berdasarkan penelitian terhadap tinjauan literatur sistematik (SLR), didapati masih lagi tiada penyelidikan khusus berkaitan dengan strategi penterjemahan elemen iltifăt ke bahasa Melayu di Malaysia. Hal ini demikian kerana kebanyakan kajian terdahulu lebih tertumpu kepada penterjemahan iltifät dalam al-Quran ke bahasa Inggeris, bahasa Perancis dan bahasa Indonesia.

\subsubsection{Rangsangan kajian penterjemahan elemen iltifāt}

Analisis tinjauan literatur sistematik (SLR) sebagaimana yang ditunjukkan dalam jadual 1 dan jadual 2 juga memberi maklumat untuk membincangkan dengan lebih terperinci tentang rangsangan atau latar belakang kajian penterjemahan elemen iltifät. Rangsangan utama yang menjadi pemangkin kepada kajian penterjemahan elemen iltifät adalah mengetengahkan strategi penterjemahan yang mampan dalam menghasilkan terjemahan iltifät yang sepadan. Rangsangan ini bagi menjawab permasalahan yang diutarakan oleh Ahmed (2004), alFarisi (2015), al-Farisi (2017), Amirdabbaghian (2017) serta al-Thawābiyyat (2019) bahawa makna teks terjemahan yang mengandungi elemen iltifăt adalah taksa sekaligus mengundang kekeliruan dalam memahami makna sebenar ayat. Rangsangan seterusnya yang menarik kajian berkaitan dengan penterjemahan elemen iltifät adalah perbezaan antara tatabahasa Arab dengan tatabahasa selainnya. Mengambil contoh kajian Durakovic (2007) dan al-'Abūdiy (2016) yang menyimpulkan bahawa terdapat konsep gaya bahasa dalam bahasa Inggeris yang hampir sama dengan konsep elemen iltifāt seperti rhetorical deixis, apostrophe dan phantasm namun tidak sepenuhnya merangkumi konsep iltifät dalam bahasa Arab. Maka, tidak hairanlah apabila Hatim \& Mason (1997) menegaskan bahawa tiada gaya bahasa yang menyerupai elemen iltifăt dalam bahasa Inggeris. Maksudi (2018) pula mengatakan bahawa gaya bahasa yang hampir sama dengan elemen iltifät berkemungkinan wujud 


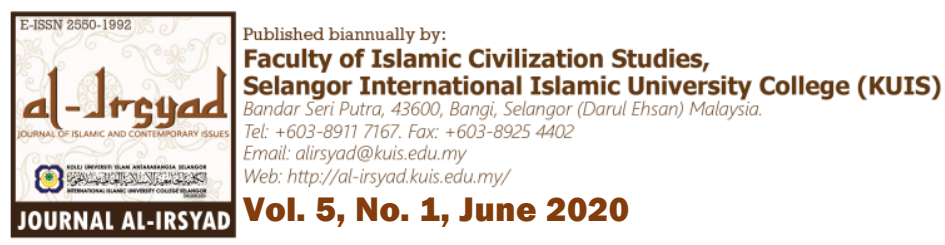

dalam bahasa lain namun, hanya bahasa Arab yang mengkategorikan elemen iltifät sebagai satu gaya bahasa dan lengkap dengan konsep dan teori. Maka, rentetan dari faktor ini menyebabkan kajian dilakukan bagi melihat kesan penggunaan elemen iltifät terhadap teks terjemahan (Amirdabbaghian, 2017; al-Ahmad, 2007; al-Badani, et. al., 2015; I'lāwiy \& Dawood, 2008; Ibraheem \& Al-Bagoa', 2010; Mahinnaz, et. al., 2012).

\subsubsection{Metode kajian}

Sekiranya diperhalusi, didapati kajian yang berkaitan dengan penterjemahan elemen iltifät hanya dijalankan dalam kajian kualitatif. Ini kerana kebanyakan kajian yang dilakukan melibatkan analisis deskriptif sesebuah teks. Sekiranya dilihat dari sudut objektif kajian pula, kebanyakannya melibatkan kajian penerokaan, perbandingan antara karya terjemahan dan penelitian ke atas elemen iltifät itu sendiri. Maka dengan sebab ini, metode kajian yang sesuai berdasarkan latar belakang dan objektif kajian sebegini adalah kajian kualitatif.

\subsubsection{Kajian deskriptif dan penerokaan baharu}

Kajian deskriptif menumpukan kepada huraian terhadap sesuatu fenomena atau isu (Creswell, 2012). Dalam kajian kualitatif, jelas daripada jadual 1 dan jadual 2 di atas bahawa kaedah analisis deskriptif dilihat lebih mendominasi kajian yang berkaitan dengan penterjemahan elemen iltifät. Dengan menggunakan kaedah ini. Būsyāqūr (2007), al-Farisi (2015), al-Badani, et. al. (2015), Ali (2015), Fayṣal \& Muṣṭafā (2017), alThawābiyyat (2019) dan Horri (2019) memilih untuk menganalisis strategi penterjemah al-Quran dalam menterjemahkan elemen iltifāt ke bahasa sasaran. Selain itu, Dawood (2008), al-Quran \& al-Azzam (2009), Ibraheem \& al-Bagoa' (2010), Mahinnaz et al. (2012) dan Amirdabbaghian (2017) pula melakukan kajian yang berkaitan dengan kesan penggunaan elemen iltifāt terhadap teks terjemahan al-Quran. Di samping itu, terdapat juga kajian yang berkaitan dengan analisis strategi penterjemahan iltifāt dalam teks selain al-Quran yang melibatkan teks sari kata (Elgebaly, 2012). Kini, kajian yang berkaitan dengan penterjemahan elemen iltifät mula dilakukan dengan lebih serius dan melibatkan penemuan baharu dalam bidang ini. Contohnya, kajian yang dilakukan oleh al-Thawābiyyat (2019) mendapati bahawa kebanyakan penterjemah al-Quran seperti Khan, Redwill dan Irfin tidak menerapkan strategi penterjemahan tertentu dalam menterjemahkan iltifät 'adad [pertukaran pola bilangan] ke bahasa Inggeris. Begitu juga Horri (2019) melalui penerokaanya telah merumuskan bahawa penterjemah al-Quran seperti Ali, Pickthall dan Arberry lebih cenderung kepada strategi terjemahan semantik dalam menterjemahkan iltifät damīr ke bahasa Inggeris.

\subsubsection{Logistik kajian penterjemahan iltifāt}

Berdasarkan jadual 1 dan jadual 2 sebelum ini, jika kajian dilihat dari sudut logistik, kajian yang berkaitan dengan penterjemahan elemen iltifät hanya melangkaui beberapa negara sahaja. Dapatan ini menyokong dapatan Ibraheem \& al-Bagoa' (2010) yang menegaskan bahawa kajian yang berkaitan dengan penterjemahan elemen iltifāt kurang terperinci dan kurang diberi perhatian oleh para pengkaji. Namun begitu, didapati kajian berkenaan paling banyak dilakukan di negara Iraq. Kajian yang berkaitan dengan penterjemahan elemen iltifāt juga turut dilakukan di luar negara Iraq iaitu negara Jordan (al-Quran \& al-Azzam, 2009; al-Thawābiyyat, 2019), Yaman (al-Badani et al., 2016), Iran (Mahinnaz et al., 2012; Horri, 2019), Algeria (Būsyāqūr, 2007), Mesir (Elgebaly, 2012), Amerika Syarikat (Ali, 2015) termasuk juga negara Malaysia (Amirdabbaghian, 2017; al-Badani, et. al., 2014; al-Badani, et. al., 2015) dan negara Indonesia (al-Farisi, 2015; al-Farisi 2017).

\subsection{Cadangan Isu Baharu Untuk Dikaji Dalam Penterjemahan Iltifät}

Analisis tinjauan literatur sistematik (SLR) sebagaimana dalam jadual 1 dan jadual 2 yang menjelaskan tentang kajian-kajian terdahulu berkaitan dengan penterjemahan elemen iltifät secara tidak langsung telah membantu kajian seterusnya untuk meneliti perkara yang telah dilakukan di samping mencari isu baharu dalam bidang ini yang menjadi objektif ketiga kajian.

Sebagaimana yang telah disebutkan sebelum ini, kajian yang berkaitan dengan penterjemahan elemen iltifät sepenuhnya didominasi oleh kajian yang menggunakan pendekatan kualitatif iaitu sebanyak 16 kajian. Oleh yang demikian, kajian berbentuk kualitatif ini boleh diterapkan sekiranya objektif kajian adalah untuk meneroka, membuat perbandingan atau memahami fenomena terhadap sesuatu isu (Stake, 2010).

Berdasarkan jadual 1 dan jadual 2 juga, kajian yang berkaitan dengan penterjemahan elemen iltifät lebih tertumpu kepada iltifät ḍamīr [pertukaran kata ganti nama] berbanding dengan elemen iltifät jenis lain 


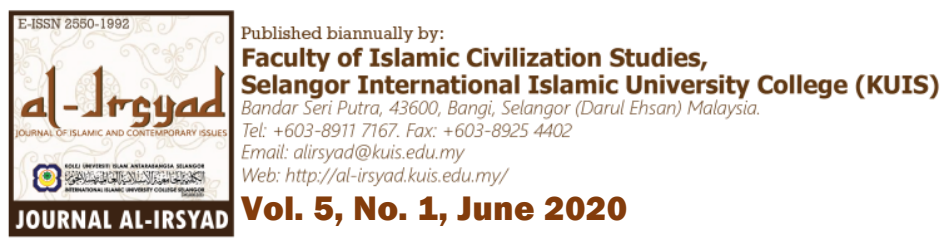

iaitu sebanyak 11 kajian. Ini kerana iltifāt ḍamīr didapati merupakan jenis iltifät yang paling kerap digunakan berbanding dengan iltifät lain dalam kebanyakan teks terutamanya teks kudus al-Quran. Mengambil contoh dapatan Būtra'at (2013) yang menunjukkan bahawa iltifät d̦amīr adalah jenis iltifät terbanyak digunakan dalam surah al-An 'àm dengan 22 kali pengulangan penggunaannya. Begitu juga iltifät d̦amìr yang terkandung dalam surah Maryam yang juga dirumuskan sebagai jenis iltifāt terbanyak dengan 8 kali kekerapan penggunaannya (Elzahra, 2017). Hakikatnya, majoriti sarjana Arab seperti Ibn al-Mu'tazz, Ibn Ja'far, al-‘Askariy, al-Halabiy dan al-Alūsiy berpendapat bahawa elemen iltifāt hanya terbatas kepada konsep pertukaran yang melibatkan kata ganti nama sahaja (al-Dīn, 2018; Fatimah, 2015; Khadijah, 2015).

Selain itu, terdapat ramai pengkaji yang memfokus kepada penterjemahan elemen iltifāt yang terkandung dalam al-Quran berbanding dengan korpus lain jika merujuk kepada jadual 1 dan jadual 2 sebelum ini. Hal ini demikian kerana penggunaan elemen iltifät adalah gaya bahasa yang paling tinggi pengulangan penggunaannya dalam al-Quran (Asnawi, 2017; Būqumraț, 2019; al-Dalīmiy \& Nūrī, 2009; Fatimah, 2015; Zaenuddin, 2018). Maka, tidak hairanlah sekiranya didapati 15 daripada 16 kajian penterjemahan elemen iltifät telah dijalankan kepada sama ada semua surah dalam al-Quran atau surah tertentu. Hanya kajian Elgebaly (2012) yang meneliti elemen iltifāt dalam teks sari kata tanpa perkaitannya dengan teks kudus al-Quran.

Sekiranya diperhalusi, kajian lampau yang berkaitan dengan penterjemahan elemen iltifät lebih tertumpu kepada penterjemahan iltifāt damīr yang terkandung dalam al-Quran terutamanya dalam surah alBaqarat. Menurut al-Khālidiy (1998) surah al-Baqarat diturunkan di Madinah yang dikategorikan sebagai surah madaniyyat. Kisah bani Israel merupakan kisah yang paling menonjol dalam surah madaniyyat (al-Khālidiy, 1998). Menurut Khayriy (2013) isi kandungan utama surah al-Baqarat adalah kisah bani Israel, pertembungan mereka dengan utusan-utusan Allah iaitu lebih daripada 115 ayat dalam surah al-Baqarat yang menceritakan tentang kisah berkenaan (Khayriy, 2013). 'Arafât (2017) menegaskan bahawa elemen iltifät damīr lebih tinggi kekerapan penggunaannya dalam wacana al-Quran yang berkait dengan penceritaan kisah bani Israel. Hal ini kerana kepelbagaian situasi yang dihadapi oleh bani Israel diceritakan dalam al-Quran dan mengisyaratkan kepada kedegilan dan kemaksiatan mereka terhadap Allah SWT ('Arafāt, 2017).

Berdasarkan jadual 1 dan jadual 2 juga, didapati kajian yang berkaitan dengan elemen iltifät lebih tertumpu kepada fenomenanya dalam al-Quran dan penterjemahannya ke bahasa Inggeris iaitu sebanyak 14 kajian. Hakikatnya, al-Quran banyak diterjemahkan ke bahasa Inggeris kerana bahasa ini adalah bahasa utama di kebanyakan negara pada masa kini (Ben Aili \& Ben Atallah, 2016). Daripada 14 kajian berkenaan, didapati 10 kajian memfokuskan strategi penterjemahan Ali terhadap elemen iltifät dalam al-Quran ke bahasa Inggeris. Hal ini demikian kerana terjemahan al-Quran nukilan Ali yang berjudul The Meaning of the Holy Qur'ān merupakan terjemahan al-Quran versi bahasa Inggeris yang berautoriti, paling popular dan kerap digunakan (alBadani, et. al., 2014). Menurut Kidwai (1987), terjemahan al-Quran nukilan Ali mengandungi nilai keaslian dan merupakan terjemahan al-Quran versi bahasa Inggeris yang paling berkualiti dalam kalangan penterjemah berbangsa India.

Di samping itu, dari sudut dapatan, Būsyāqūr (2007), Ali (2015), al-Badani et al. (2016) serta Fayșal \& Mușțafā (2017) mengatakan bahawa strategi penterjemahan terbaik untuk menterjemahkan elemen iltifăt adalah strategi pengembangan makna [expansion strategy]. Menurut al-Badani et. al (2016), strategi ini lebih cenderung memberi maklumat atau huraian tambahan dalam kurungan. Namun, al-Farisi (2015) berpendapat bahawa strategi pengembangan makna beserta bold akan menjadikan teks sasaran yang mengandungi maklumat dalam kurungan kelihatan lebih jelas. al-Badani, et. al. (2014) juga menegaskan bahawa strategi penterjemahan literal tidak sesuai diterapkan dalam penterjemahan elemen iltifät. Namun, didapati Kementerian Hal Ehwal Agama Indonesia cenderung kepada strategi penterjemahan literal dalam menterjemahkan elemen iltifāt (alFarisi, 2015). Menurut al-Faori (2017) sekiranya elemen iltifät diterjemahkan dengan strategi penterjemahan literal, maka fungsi balaghah yang melatari elemen iltifät berkenaan tidak dapat dikesan dalam teks sasaran. alBadani, et. al. (2014) dan al-Badani, et. al. (2016) juga menegaskan bahawa strategi pengembangan makna hanya berfungsi menarik perhatian pembaca teks sasaran kepada elemen iltifät, namun tidak menyerlahkan fungsi balaghah yang melatari setiap elemen iltifät. Hal ini menyebabkan pembaca teks sasaran tidak memperoleh makna sebenar kesan dari penggunaan elemen iltifät.

Oleh yang demikian, kesimpulan daripada perbincangan ini, didapati bahawa ruang dan peluang kajian penterjemahan iltifät sangat luas. Sekiranya diperhalusi, didapati kajian lampau yang berkaitan dengan penterjemahan elemen iltifāt lebih tertumpu kepada penterjemahan iltifät d̦amīr dalam al-Quran ke bahasa Inggeris. Sewajarnya, kajian penterjemahan iltifāt damīr dalam al-Quran ke bahasa Melayu juga turut disemarakkan seperti terjemahan al-Quran nukilan Abdullah Basmeih yang mana diiktiraf keberkesanannya dan menjadi rujukan kepada orang Melayu semenjak tahun 1968 (Hasan, 2000). 


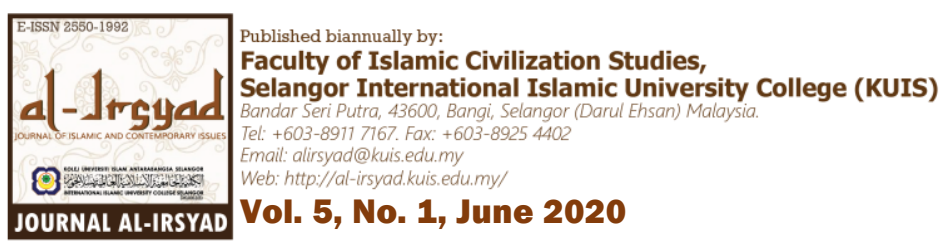

\section{Kesimpulan}

Penggunaan kaedah tinjauan literatur sistematik (SLR) menjelaskan beberapa isu berkaitan dengan kajian penterjemahan elemen iltifăt. Hasil tinjauan ini mendapati kajian penterjemahan iltifät secara ringkasnya tertumpu kepada strategi penterjemahan iltifāt damīr yang terkandung dalam al-Quran ke bahasa Inggeris dan penilaian keberkesanan strategi yang diterapkan bagi menangani fenomena ini. Namun begitu, kebanyakan strategi yang diterapkan gagal menyerlahkan fungsi balaghah yang melatari setiap elemen iltifät. Ini kerana iltifät merupakan gaya bahasa yang dianggap janggal atau tiada persamaan dalam bahasa sasaran dan teks terjemahan yang mengandungi elemen iltifät adalah taksa sekaligus mengundang kekeliruan dalam memahami makna sebenar ayat. Situasi ini mendorong penterjemah untuk mengabaikan elemen iltifät dalam teks sasaran. Walau bagaimanapun, pengabaian terhadap penterjemahan iltifāt damīr yang mengandungi fungsi balaghah tertentu menyebabkan pembaca teks sasaran tidak memperoleh makna sebenar kesan dari penggunaan iltifät damīr.

Selain itu, justifikasi memilih pendekatan kualitatif berbanding dengan kuantitatif sebagai reka bentuk kajian penterjemahan elemen iltifāt seterusnya adalah wajar berdasarkan kepada dominasi kajian penterjemahan iltifät sebelum ini. Juga berdasarkan sorotan literatur tersebut, terhasilnya isu baharu yang mendorong kepada keperluan penghasilan strategi penterjemahan elemen iltifät yang mampan dalam menyerlahkan terjemahannya yang sepadan ke bahasa Melayu. Perlu diketahui bahawa masih tiada kajian yang membincangkan secara khusus mengenai penterjemahan elemen iltifät damīr ke bahasa Melayu di Malaysia. Kebanyakan kajian lepas lebih tertumpu kepada penterjemahan elemen iltifāt damīr ke bahasa asing yang lain terutamanya bahasa Inggeris dan termasuk juga bahasa Perancis. Strategi penterjemahan yang dibincangkan oleh pengkaji-pengkaji terdahulu hanya menekankan penjelmaan elemen iltifät dalam teks sasaran tanpa mengambil kira fungsi balaghah yang melatari setiap elemen berkenaan yang turut memberi kesan kepada makna. Oleh yang demikian, kesedaran dan tindakan untuk menghasilkan strategi penterjemahan yang mampan perlu dijalankan bagi membendung isu ini daripada terus berlaku. Kajian seperti strategi penterjemahan iltifāt ḍmīr yang terkandung dalam al-Quran ke bahasa Melayu wajar ditangani secara tuntas dalam prakarsa penterjemahan, apatah lagi dalam usaha mempertingkatkan dan memelihara ketepatan dan mutu terjemahan teks kudus al-Quran demi kepentingan umat Islam.

\section{Rujukan}

'Arafāt, U. A. (2017). Athar al-siyāq 'alā uslūb al-iltifāt al-muta'allaq bi ban̄i isrāil fì sūrat al-Baqarat. Dirāsāt, 'Ulūm al-Shar 'iyyat wa al-Qanūn. 44(4), 243-255.

Abdul Raof, H. (2005). Pragmalinguistic forms in cross-cultural communication: contribution from Qur'an translation'. In Translation, Representation and Identity in Intercultural Communication. Edited by Said Faiq. Sharjah: American University of Sharjah. pp. 115-130.

Abdullah, N. (2017). Asbāb al-ḍa'f fī madā maqrū'iyyat al-nuṣūṣ al-Qur’āniyyat al-mutarjamah ilā almalayūwiyyah. Al-Irsyad: Journal of Islamic and Contemporary Issues, 2(1), 73-82.

Abū al-Su'ūd, M. M. (t.th.). Tafsīr Ab̄̄ al-Su'ūd; irsyād al- 'aql al-salīm ilā mazāyā al-qur'ān al-karīm. Beirut: Dār Iḥ̂ā' al-Turāth al-‘Arabiy.

Abu Bakar, M. H. (2012). Terjemahan kata kerja berposisi arab-melayu dalam kitab Mustika Hadis. Tesis PhD. Serdang: Universiti Putra Malaysia.

Ahmed, H. (2004). A new approach to the study of the qur'an. India: Goodword Books.

Akbari, N. (2018). The saracen's codex. United Kingdom: Author House.

Al Farisi, Z. (2015). Speech act of iltifat and its indonesian translation problems. Indonesian Journal of Applied Linguistics, 4(2), 78-90. https://doi.org/10.17509/ijal.v4i2.685

Al-'Abūdi, I. K. (2016). Apostrophe in English and Arabic. Majallat Kulliyyat al-Asāsiyyat li al-'Ulūm alTarbawiyyat wa al-Insāniyyat, Jāmi 'at Bābil, 26, 185-202.

Al-Asfahāni, R. (2009). Mufradāt alfāzz al-Qur'ān. sunt. Șafwān 'Adnān Dāwūdiy. Beirut: Dār al-Qalam-Dār alSyāmiyyat.

Al-Badani, N. A. M. A., Awal, N. M. \& Zainudin, I. S. (2015). The translation of reference switching (iltifat) in surat al-Baqarah. Journal of Social Sciences and Humanities. Special Issue (2), 140-148.

Al-Badani, N. A. M. A., Awal, N. M., Zainudin, I. S. \& Aladdin, A. (2016). Expansion strategy in the translation of iltifāt in sūrat al-Baqarah. Arab World English Journal. Special Issue (5), 54-65. 


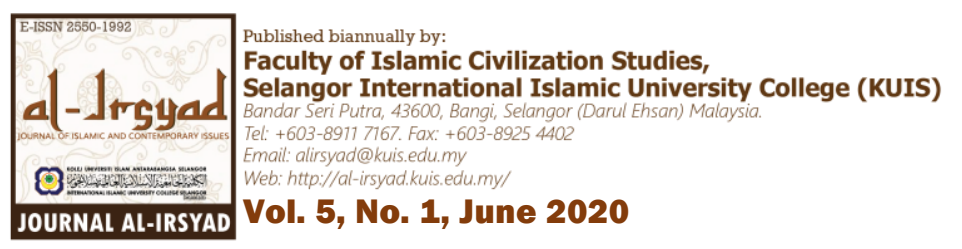

Al-Badani, N., Awal, N., Zainudin, I., \& Aladdin, A. (2014). Reference switching (iltifāt) in Arabic and its translation into English: an intertexual analysis. International Journal of Asian Social Sciences. 4(6), 791-805.

Al-Banāni, K. M. A. (1993). al-Iltifāt fì al-Qur'ān al-Karìm ilā akhir sūrat al-Kahf. Tesis Sarjana. Mekah: Umm al-Qurā University.

Al-Dalīmi, A. A. S \& Nūrī, M. M. (2009). Fann al-iltifāt fī al-qirā'āt al-sab‘. Ādāb al-Rāfidīn, 55, $204-224$.

Al-Dīn, S. (2018). Balāghat al-Iltifât al-Qur'āniy 'inda al-Alūsiy. al-Ta 'līmiyyah. 5(16), 260-269.

Al-Faori, N. A. D. M. (2017). Equivalence problems in translation. Sino-US English Teaching, 14(2), 86-97. https://doi.org/10.17265/1539-8072/2017.02.003.

Al-Farisi, M. Z. (2017). Readability analysis of the imperative verses translation of the holy Quran. CONAPLIN and ICOLLITE 2017 - Tenth International Conference on Applied Linguistics and First International Conference on Language, Literature and Culture. Bandung: CONAPLIN and ICOLLITE. https://doi.org/10.5220/0007171105710575.

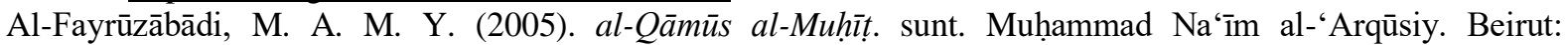
Muassasat al-Risālat.

Ali, A. M. A. (2015). A Stylistic study of morpho-semantic shifts in some selected english translations of the glorious qur'an. Tesis PhD. Mesir: Cairo University.

Al-Jarmān, A. R. A. S. (2016). Uslūb al-iltifāt fī al-Qư'ān al-Karīm wa atharuhu fī al-ma'nā 'inda almufassirīn. Hawliyyat Kulliyat al-Dirāsāt al-Islamiyyat wa al-'Arabiyyat. 33(2), 1001-1049.

Al-Khālidi, S. (1998). al-Syakhșiyyat al-Yahūdiyyat min khilāl al-Qur'ān. Damascus: Dār al-Qalam.

Al-Quran, M., \& Al-Azzam, B. (2009). Apostrophe: a rhetorical device of the Qur'an. Retrieved from https://pdfs.semanticscholar.org/e6eb/9babfcec9f497017bca433639b362fe31d0d.pdf

Al-Thawābiyyat, H. H. (2019). Tarjamat al-iltifāt al-'adadiy fī al-Qur'ān al-Karīm. Dirāsāt al-'Ulūm alInsāniyyat wa al-Ijtima iyyat. 46(2), 334-352.

Al-Zamakhshari, Ā. Q. (1998). Asās al-Balāghaț. sunt. Muhammad Bāsil 'Uyūn al-Sūd. Beirut: Dār al-Kutub al-'Ilmiyyat.

Amirdabbaghian, A. (2017). Translation of power and solidarity pronouns in Qur'anic rhetoric. Journal of Language and Translation. 7(3), 65-73.

Amirudin, M. (2013). Stilistika gaya bahasa al-qur'an (kajian ayat-ayat iltifat; analisis struktur dan makna). Indonesia: IAIN Raden Intan Lampung.

Asnawi, A. R. (2017). Uslūb iltifăt fì al-juz' al-akhīr min al-Qur'ān al-Karīm. Lisanudhad Journal. 4(1), 121137.

Basmeih. A. (1983). Tafsir pimpinan Ar-Rahman kepada pengertian Al-Qur'an. Kuala Lumpur: Dār al-Fikr.

Baumeister, R. F., \& Leary, M. R. (1997). Writing Narrative Literature Reviews. Review of general psychology. $1(3), 311-320$.

Bell, R. T. (2012). Terjemahan produk dan proses. Terj. Zuraidah Ibrahim Bell dan Syed Nurulakla. Kuala Lumpur: Dewan Bahasa dan Pustaka.

Bem, D. J. (1995). Writing a review article for psychological bulletin. Psychological Bulletin. 118, $172-177$.

Ben Aili, H., \& Ben Atallah, S. (2016). Problems of translating Quranic Lexis a comparative study of two translations of verses from chapter. Tesis Sarjana. Algeria: Kasdi Merbah University-Ouargla.

Būqumrat, U. (2019). Mușțalaḥ al-Iltifăt min al-rasīs ilā al-ta'sīs. Majallat Dirāsāt Mu 'ạṣirat. 3(2), 145-150.

Burton, J. (1988). Linguistic errors in the Qur'ān. Journal of Semitic Studies. 33(2), 181-196. https://doi.org/10.1093/jss/XXXIII.2.181.

Būsyāqūr, Z. (2007). Uslūb al-Iltifāt wa tarjamatuhu ilā al-lughat al-Faransiyyat; dirāsat naqdiyyat muqāranat min khilāl thalāth namāadhij li tarjamāt al-Qur'ān. Tesis Sarjana. Algeria: Jāmi 'at Mantūrī.

Būtra'at, A. H. (2013). Șuwar wa dilālāt al-iltifāt fĩ sūrat al-An'ām. Majallat 'Ulūm al-Lughat al-'Arabiyyat wa Ādābuha. 5, 150-164.

Catford, J.C. (1965). A Linguistic theory of translation. United Kingdom: Oxford University Press.

Dawood, N. (1990). The Koran translated. Amerika Syarikat: Doubleday.

Durakovic, E. (2008). Rhetorical twist in the Qur'an. Jordan Journal of Islamic Studies. 4(1), 9-15.

Elgebaly, N. (2019). Accommodating audience needs in islamic subtitling: a case of manipulation? Meta Translators' Journal. 57(2), 423-438. https://doi.org/10.7202/1013954ar.

Elzahra, M. U. (2017). Uslūb al-Iltifāt fì sūrat Maryam; dirāsat tahlīliyyat balaghiyyat. Jogjakarta: Universiti Islam Negeri Sunan Kalijaga.

Fatimah, E. (2015). Uslūb al-Iltifāt wa asrāruhu al-balāghiyyaț; dirāsat taṭbīqiyyat 'alā sūrat Yūnus. Jakarta: Universiti Islam Negeri Syarif Hidayatullah. 


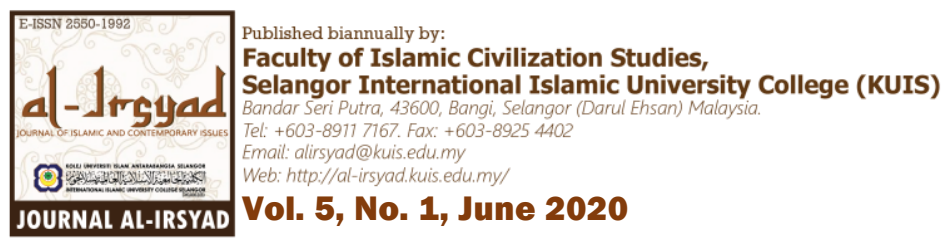

Fayṣal, T. A. \& Mușțafā, I. M. A. (2017). Tarjamat 'udūl al-ṣarfiy wa al-mufradātī fī al-Qu'rān al-Karīm ilā allughat al-injilīziyyat. Majallat al-Dirāsat al-Tārīkhiyyat wa al-Haḍariyyat, 9(29), 357-378.

Harti, R. A. (2018). Uslūb al-Iltifāt fì sūrat al-Nisā': dirāsat taḥlīliyyat balāghiyyat. Tesis Sarjana. Indonesia: Universiti Islam Negeri Sunan Kalijaga.

Hasan, W. R. (2000). Sumbangan Sheikh Abdullah Basmeih dalam bidang tafsir: kajian khusus terhadap kitab tafsir pimpinan Al-Rahman. Tesis Sarjana. Kuala Lumpur: Universiti Malaya.

Hassan, B. A. (2011). Literary translation: aspects of pragmatic meaning. United Kingdom: Cambridge Scholars Publishing.

Hatim, B., \& Mason, I. (1997). The translator as communicator. London: Routledge.

Horri, A. (2019). Semantic strategy: a dominant method in translating iltifat in three english translations of the Quran. Translation Studies Quarterly. 17(66), 7-22.

I'lāwi, N. M. \& al-Aḥmad. A. M. (2007). Iltifāt al-'adad fī namādhij min al-Qur'ān al-Karīm. Dirasat: Human And Social Sciences. 34, 717-727.

Ibn 'Āsyūr, M. T. (1984). Tafsīr al-taḥrīr wa al-tanwīrr. Tunisia: al-Dār al-Tūnisiyyat li al-Nasyr.

Ibn Fāris, A. H. A. (1979). Mu ‘jam maqāȳ̄s al-lughat. Beirut: Dār al-Fikr li al-Ṭibā'at wa al-Nasyr wa alTawzī'.

Ibn Manẓūr, J. M. (1993). Lisān al- 'Arab. Beirut: Dār Șādir.

Ibraheem, Q., \& al-Bagoa', M. A. (2010). Grammatical shifts in the glorious qur'an and their renderings into english. Adab al-Rafidīn, 57, 113-138.

Ismā'īl, S. (2011). al-Iltifāt bayn 'ulūm al-balāghat al-thalāthat. Algeria: Jāmi'at Warqalat.

Khadījat, L. (2015). Athar al-Iltifāt fĩ al-manhaj al-balāghiy al-tafsīriy; al-dūrr al-mașūn. Majallat al- 'Ulūm alInsāniyyat, 38(39), 201-221.

Khayri, M. W. (2013). al-Qadiyyat al-Yahūdiyyat fì sūrat al-Baqarat. Retrieved from https://www.islamweb.net/ar/article/190939/ (on 2019 Sept 13).

Kidwai, A. (1987). Translating the untranslatable: a survey of english translations of the quran. Retrieved from http://www.soundvision.com/Info/quran/english.asp.

Lakhḍar, I.(2016). Uslūb al-Iltifāt fì al-Qur'ān al-Karīm: sūraț al-Kahfi unmūdhajan. Tesis Sarjana. Algeria: Jāmi'at 'Abd al-Hamīd bin Bādīs Mustaghānim.

Mahinnaz, M., Zahedi, K., \& Nasiri, F. (2012). Iltifat, grammatical person shift and cohesion in the holy Quran. Global Journal of Human Social Science. 12(2), 45-52.

Maksudi, F. (2018). Uslūb al-Iltifāt fì sūratay al-Nis̄̄' wa al-Tawbaț; dirāsat tahlīliyyat balāghiyyat. Tesis Sarjana. Indonesia: Universiti Islam Negeri Sunan Kalijaga.

Michie, S., \& Williams, S. (2003). Reducing work related psychological ill health and sickness absence: a systematic literature review. Occupational and environmental medicine. 60(1), 3-9.

Mukhtar, M. (2018). Uslūb al-Iltifāt wa dilālātuhu fì al-Qur'ān al-Karīm: dirāsat taṭbīqiyyat. Gombak: IIUM Press.

Newmark, P. (1988). A Textbook of translations. Hemel Hempstead: Prentice Hall.

Nida, E. A. (1964). Toward a science of translating: with special reference to principles and procedures involved in Bible translating. Leiden: E.J. Brill.

Omer, B. A. (2017). translation loss in translation of the glorious Quran with special reference to verbal similarity. Retrieved from https://www.ijmrnd.com/assets/pdf/english-linguistics/Translation-Loss-inTranslation-of-the-Glorious-Quran,-with-Special-Reference-to-Verbal-Similarity-by-Batoul-AhmedOmer.pdf

Qaḥtān, T. A. R. (2005). al-Iltifāt fì al-balāghat al- 'arabiyyaț wa namādhij min asrār balāghatihi fì al-Qur'ān al-Karim. Journal of Social Studies. 10(1), 1-30.

Rābḥi, M. (2014). Uslūb al-Iltifāt bi maqāmāt al-ḍamāir: sūrat Yūnus unmūdhajan. Tesis Sarjana. Algeria: Jāmi'at Muhammad Khayḍar Biskarat.

Rafiqul-Haqq, M., \& Newton, P. (1996). The Quran: grammatical errors. https://www.answeringislam.org/Authors/Newton/grammar.html (retrieved on 2019 Sept 13).

Robinson, N. (1996). Discovering the Qur'an: a contemporary approach to a veiled text. United Kingdom: SCM Press.

Siddiqi, N., House, A. O., \& Holmes, J. D. (2006). Occurrence and outcome of delirium in medical in-patients: a systematic literature review. Age and Ageing. 35(4), 350-364.

Stake, R. E. (2010). Qualitative research: studying how things work. New York: The Guilford Press.

Ṭabl, Ḥ. (1998). Uslūb al-Iltifāt fì al-balaghat al-Qur'āniyyat. Kaherah: Dār al-Fikr al-'Arabiy.

Venuti, L. (2000). The Translation studies reader. London, New York: Routledge Taylor \& Francis Group. 


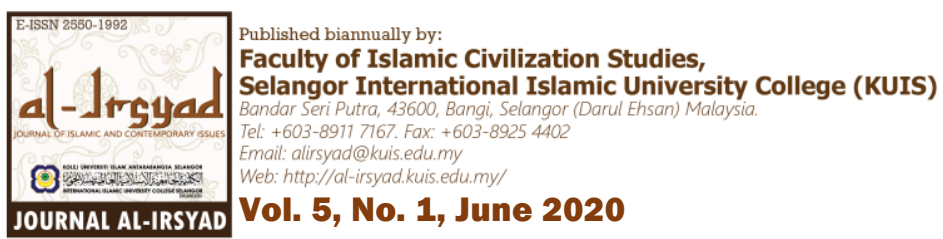

Wuryantoro, A. (2018). Pengantar penerjemahan. Yogyakarta: Penerbit Deepublish.

Zaenuddin, M. (2018). Uslub Iltifât dalam Al-Quran. TAJDID, 25(2), 171-186. doi:10.36667/tajdid.v25i2.325 